\title{
In Situ Spectroscopic Studies of Proton Transport in Zeolite Catalysts for $\mathrm{NH}_{3}-\mathrm{SCR}$
}

\author{
Peirong Chen * and Ulrich Simon* \\ Institute of Inorganic Chemistry and Center for Automotive Catalytic Systems Aachen, \\ RWTH Aachen University, 52074 Aachen, Germany \\ * Correspondence: peirong.chen@ac.rwth-aachen.de (P.C.); ulrich.simon@ac.rwth-aachen.de (U.S.); \\ Tel.: +49-241-809-9386 (P.C.); +49-241-809-44644 (U.S.)
}

Academic Editor: Juan J. Bravo-Suarez

Received: 26 October 2016; Accepted: 9 December 2016; Published: 14 December 2016

\begin{abstract}
Proton transport is an elementary process in the selective catalytic reduction of nitrogen oxides by ammonia ( $\mathrm{DeNO}_{x}$ by $\mathrm{NH}_{3}$-SCR) using metal-exchanged zeolites as catalysts. This review summarizes recent advancements in the study of proton transport in zeolite catalysts using in situ electrical impedance spectroscopy (IS) under $\mathrm{NH}_{3}$-SCR reaction conditions. Different factors, such as the metal cation type, metal exchange level, zeolite framework type, or formation of intermediates, were found to influence the proton transport properties of zeolite $\mathrm{NH}_{3}-\mathrm{SCR}$ catalysts. A combination of IS with diffuse reflection infrared Fourier transformation spectroscopy in situ (in situ IS-DRIFTS) allowed to achieve a molecular understanding of the proton transport processes. Several mechanistic aspects, such as the $\mathrm{NH}_{3}$-zeolite interaction, NO-zeolite interaction in the presence of adsorbed $\mathrm{NH}_{3}$, or formation of $\mathrm{NH}_{4}{ }^{+}$intermediates, have been revealed. These achievements indicate that IS-based in situ methods as complementary tools for conventional techniques (e.g., in situ X-ray absorption spectroscopy) are able to provide new perspectives for the understanding of $\mathrm{NH}_{3}-\mathrm{SCR}$ on zeolite catalysts.
\end{abstract}

Keywords: proton transport; impedance spectroscopy; DRIFTS; reaction mechanism; $\mathrm{NO}_{x}$ emission control; $\mathrm{NH}_{4}{ }^{+}$intermediates

\section{Introduction}

Selective catalytic reduction (SCR) is one of the key technologies to reduce nitrogen oxide emissions $\left(\mathrm{NO}_{x}\right)$ from "lean-burn" engines and power plants [1-3]. Because of their superior activity and hydrothermal stability, $\mathrm{Cu}$ - or Fe-exchanged zeolites are widely applied as SCR catalysts, especially in diesel-powered automobiles [3,4]. To meet the continuously tightening $\mathrm{NO}_{x}$ emission legislation, it is necessary to further improve the performance of the metal-exchanged zeolite catalysts in SCR, which requires understanding more deeply both the reaction mechanisms and the real-time physico-chemical properties of the zeolite catalysts under operational conditions [2-6].

For SCR reactions using $\mathrm{NH}_{3}$ as a reductant $\left(\mathrm{NH}_{3}-\mathrm{SCR}\right.$; see Equations (1)-(3) for different reaction routes depending on the $\mathrm{NO}_{x}$ composition):

$$
\begin{gathered}
4 \mathrm{NH}_{3}+4 \mathrm{NO}+\mathrm{O}_{2} \rightarrow 4 \mathrm{~N}_{2}+6 \mathrm{H}_{2} \mathrm{O} \text { (standard SCR), } \\
2 \mathrm{NH}_{3}+\mathrm{NO}+\mathrm{NO}_{2} \rightarrow 2 \mathrm{~N}_{2}+3 \mathrm{H}_{2} \mathrm{O} \text { (fast SCR), } \\
8 \mathrm{NH}_{3}+6 \mathrm{NO}_{2} \rightarrow 7 \mathrm{~N}_{2}+12 \mathrm{H}_{2} \mathrm{O}\left(\mathrm{NO}_{2} \mathrm{SCR}\right) .
\end{gathered}
$$

One of the fundamental issues is to understand the $\mathrm{NH}_{3}$-zeolite interaction. This interaction has been known to largely determine the storage capability, the uptake and release energetics, 
and the reactivity of $\mathrm{NH}_{3}$ within zeolite catalysts [3,7], and eventually the catalytic performance of the zeolite catalysts in $\mathrm{NH}_{3}$-SCR. Considerable advancements have been achieved by means of, for example, temperature-programmed desorption (TPD), infrared spectroscopy, and X-ray based methods such as Extended X-Ray Absorption Fine Structure, X-ray Absorption Near Edge Structure, X-ray Emission Spectroscopy (all using $\mathrm{NH}_{3}$ as a probe molecule) [7-13]. Nevertheless, more elementary processes associated with the $\mathrm{NH}_{3}$ storage and conversion, in particular, the proton transport, are not fully understood.

It is known that proton transport, which can take place either from the bridging hydroxyl groups (Brønsted acid sites) to reactant molecules or between the reaction intermediates, plays an important role in a series of catalytic reactions such as methylation [14], cracking and methanol-to-olefin [15,16], as well as abatement of $\mathrm{NO}_{x}$ emissions $[3,4,17]$. Comprehensive experimental and theoretical investigations had been performed over zeolites with different framework types (FAU, BEA, MFI, FER, CHA, etc.), in order to understand and take advantage of the proton transport processes for further improving the catalytic performance of zeolites [18-22]. Density functional theory (DFT) calculations revealed that proton transfer takes place in several elementary processes in $\mathrm{NH}_{3}-\mathrm{SCR}$ reactions over zeolite catalysts, including $\mathrm{NO}$ oxidation, fast $\mathrm{SCR}, \mathrm{NO}_{2}-\mathrm{SCR}, \mathrm{NH}_{3}$ oxidation and $\mathrm{N}_{2} \mathrm{O}$ decomposition [12,20,22,23]. For Cu-ZSM-5 catalyzed NO decomposition, the presence of protons was found to significantly lower the energy barrier for the NO activation on $\mathrm{Cu}$ sites [24]. Although the proton transport processes can be probed by ${ }^{1} \mathrm{H}$ MAS NMR spectroscopy under well-controlled conditions $[12,19,21]$, studies under technically relevant reaction conditions are practically challenging. In the last years, we applied electrical impedance spectroscopy (IS) to study the proton transport in various zeolites (such as H-ZSM-5, Fe-ZSM-5, Cu-ZSM-5, Cu-SSZ-13, $\mathrm{Cu}-\mathrm{SAPO}-34$, etc.) as $\mathrm{NH}_{3}$-SCR catalysts under in situ or operando conditions [17,25-31]. In $\mathrm{NH}_{3}$-SCR over zeolite catalysts, the adsorption of $\mathrm{NH}_{3}$ molecules on Brønsted acid sites leads to the formation of ammonium ions $\left(\mathrm{NH}_{4}{ }^{+}\right)$, which interact further with $\mathrm{NH}_{3}$ molecules forming $\mathrm{NH}_{4}{ }^{+} \cdot\left(\mathrm{NH}_{3}\right)_{n}$ complexes at low temperatures [2]. The formed $\mathrm{NH}_{4}{ }^{+}$and $\mathrm{NH}_{4}{ }^{+} \cdot\left(\mathrm{NH}_{3}\right)_{n}$ complexes, which can provide additional paths or carriers for proton transport [26,32-34], lead to increased proton conductivities which can be monitored by IS in a broad frequency range ( $\mathrm{mHz}-\mathrm{GHz})[27,32-36]$. The consumption of adsorbed $\mathrm{NH}_{3}$, either by desorption or SCR conversion, leads to decreased conductivity due to a loss of proton carriers $[17,26]$. A further combination of IS and diffuse reflection infrared Fourier transformation spectroscopy (in situ IS-DRIFTS) allowed us to achieve a molecular understanding of the proton transport processes and their impact in $\mathrm{NH}_{3}$-SCR catalysis [17,27-29].

In this review, we will briefly introduce the physical background and instrumentation of in situ IS and in situ IS-DRIFTS (Section 2). In Section 3, we will summarize the mechanisms and influential factors of $\mathrm{NH}_{3}$-supported proton transport in zeolite catalysts, and the impact of proton transport in $\mathrm{NH}_{3}$-SCR catalysis. The future perspectives, which arise from the achieved understanding, will be discussed at the end (Section 4).

\section{Theory and Instruments}

\subsection{Theory of Impedance Spectroscopy}

Impedance spectroscopy is an electric perturbation technique, and can be employed to analyze the mobility of ions in solid materials [37,38]. In a typical IS measurement over zeolite, an alternating voltage $U(\omega)$ with angular frequency $\omega$ and amplitude $U_{0}$ is applied to form an electric field over a zeolite in thermodynamic equilibrium. A response of the system, i.e., a movement of the mobile cations either via translation motion or a local displacement, is induced by the electric perturbation, and can be macroscopically measured as a current $I(\omega)$. The complex impedance $Z(\omega)$ is defined as

$$
Z(\omega)=U(\omega) / I(\omega)
$$


and can be described by a real part $Z^{\prime}$ and an imaginary part $Z^{\prime \prime}$. Both depend on the angular frequency $\omega$ :

$$
Z(\omega)=Z^{\prime}(\omega)+j Z^{\prime \prime}(\omega)
$$

In the analysis of complex impedance $Z(\omega)$, low-frequency phenomena such as the sample/electrode interface polarization can be identified from the dominating low-frequency tail of the traditional Argand representation (also known as Nyquist plot; the real part $Z$ ' is plotted against the imaginary part $Z^{\prime \prime}$; see Figure 1a for an example) [39]. The high-frequency processes are more visible in the Modulus plot, which shows the imaginary part of the Modulus $M$, i.e., $M^{\prime \prime}(\omega)$, against the frequency $f$ (Figure 1b). The modulus $M^{\prime \prime}(\omega)$ is defined as

$$
M^{\prime \prime}(\omega)=\omega C_{0} Z^{\prime}(\omega),
$$

wherein $C_{0}$ is the capacity of the empty capacitor, i.e., the geometric capacitance. Thereby, two distinct relaxation processes, i.e., the local dipolar relaxation (as visualized by the maximum at high-frequency range) and the long-range proton transport (as visualized by the maximum at low-frequency range) can be clearly distinguished in one spectral representation.
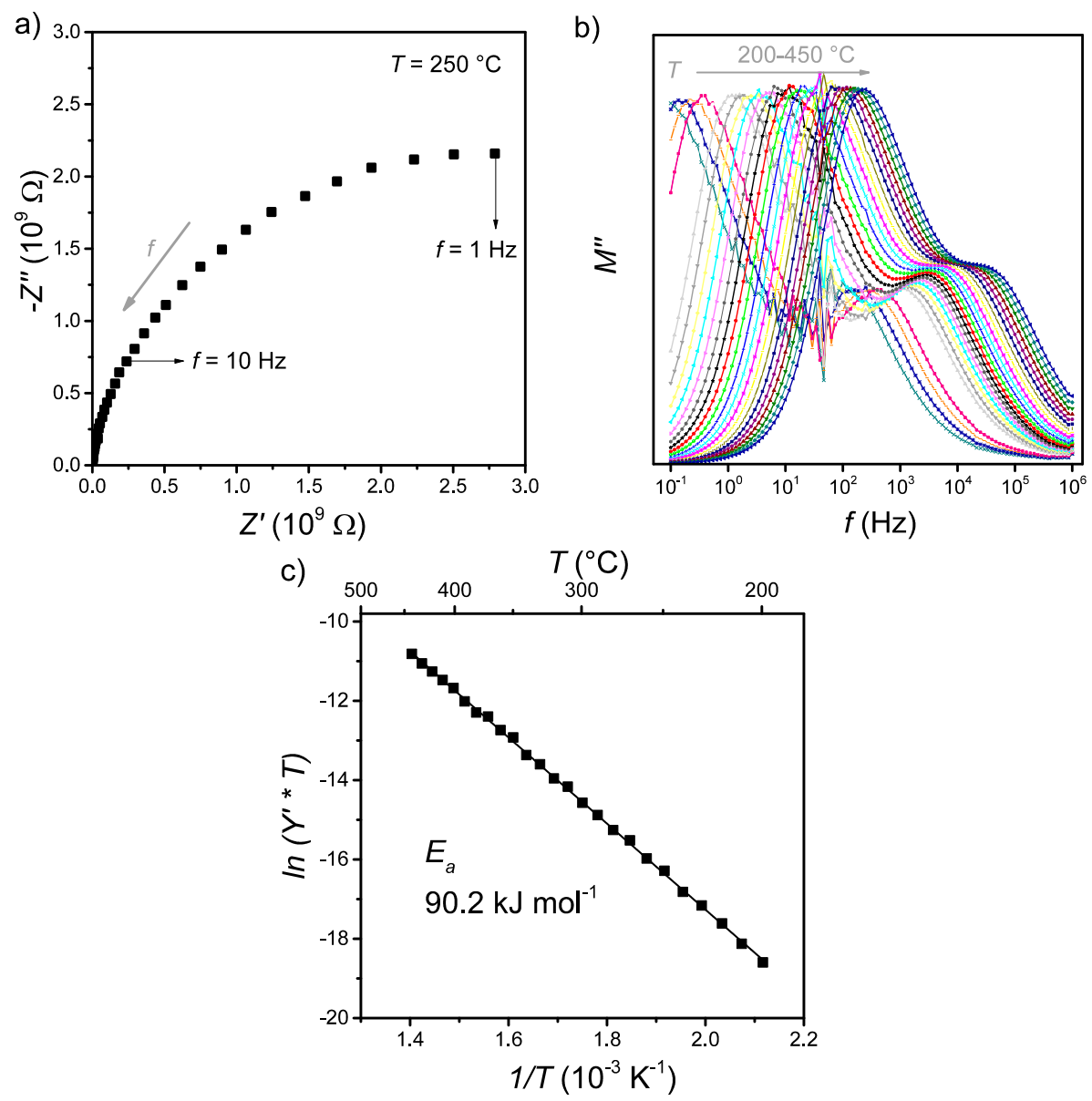

Figure 1. (a) Argand diagram (plot of the imaginary part of the impedance $-Z^{\prime \prime}$ versus the real part of the impedance $Z^{\prime}$ in the complex plane) of dehydrated H-ZSM-5 (Si/Al 13.5) at $250{ }^{\circ} \mathrm{C}$; the gray arrow indicates the increase of frequency; (b) modulus spectra of the imaginary part $M^{\prime \prime}$ versus frequency $f$ of H-ZSM-5 at temperatures $200-450{ }^{\circ} \mathrm{C}$; the gray arrow indicates the increase of temperature; (c) Arrhenius-like plot of logarithmic proton conductivity at resonance frequencies (in low-frequency range) derived from the Modulus spectra in (b). Reproduced with permission from [29]. The Royal Society of Chemistry, 2016. 
The long-range proton transport within the zeolites is temperature-dependent, and can be represented using the Arrhenius equation:

$$
\ln \left(Y^{\prime} \times T\right) \sim \ln \left(\sigma_{T}\right)=A-E_{a} /\left(k_{\mathrm{B}} \times T\right),
$$

where $Y^{\prime}$ is the real part of the admittance, i.e., $Y(\omega)=1 / Z(\omega)$, at the resonance frequency $f_{\text {res }}$ (determined according to the low-frequency maximum in the Modulus plot at the respective temperature), $A$ is the pre-exponential factor (which depends on the charge and number of the mobile species, its on-site oscillation frequency and the hopping distance [38]), $E_{a}$ is the activation energy of the proton transport process, $\sigma$ is the specific conductivity of the zeolite, $k_{\mathrm{B}}$ is the Boltzmann constant, and $T$ is the temperature. An example is shown in Figure 1c for an Arrhenius-like representation of IS results over the zeolite H-ZSM-5.

\subsection{Instruments for In Situ IS and In Situ IS-DRIFTS}

The measurement configurations for in situ IS and in situ IS-DRIFTS are schematically displayed in Figure 2a,b, respectively. For both methods, the zeolite catalysts were deposited as a thick film on screen-printed interdigital electrodes (IDEs) comprised of an alumina substrate with gold electrodes on the front side and an integrated heater on the reverse side. In this way, an excellent electrical contact between the zeolite film and the IDE structure can be achieved [30]. An external power supply is used for temperature control via resistive heating. Temperature calibration was performed for each sample with a pyrometer for the remote monitoring of temperature on the surface of zeolite film. The gas composition is controlled by mass flow controllers (MFCs) dosing different gases such as $\mathrm{NO}, \mathrm{O}_{2}, \mathrm{NH}_{3}$ and $\mathrm{N}_{2}$ (carrier gas). Prior to each measurement, the zeolite sample was pretreated at high temperatures (usually at $400{ }^{\circ} \mathrm{C}$ in 10 vol. $\% \mathrm{O}_{2}$ for $1 \mathrm{~h}$ ) to remove any adsorbed water or hydrocarbon contaminants. The electrical impedance of the sample is measured with an impedance analyzer range up to $10^{14} \Omega( \pm 1 \%)$. The voltage is set to $0.1 \mathrm{~V}(\mathrm{rms})$ for all measurements to stay in the linear response regime.

a)

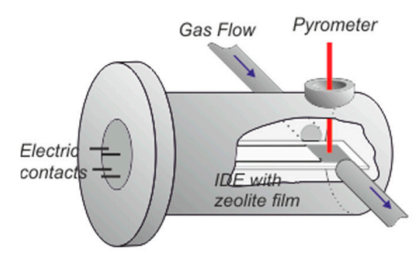

b)

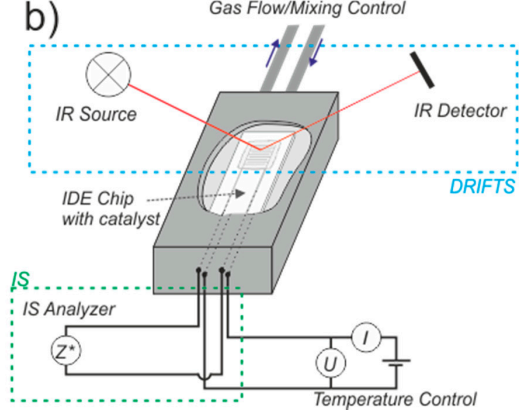

Figure 2. Schematic illustrations of the measurement configurations for (a) in situ impedance spectroscopy (IS) and (b) in situ IS and diffuse reflection infrared Fourier transformation spectroscopy (in situ IS-DRIFTS). (a) Reproduced with permission from [30]; (b) adapted with permission from [28], Elsevier, 2016.

The in situ IS measurements were carried out using a homemade reaction chamber (Figure 2a). For in situ IS-DRIFTS measurements, a commercial high-temperature reaction chamber (Harrick Scientific Products, Pleasantville, NY, USA) was modified to allow the introduction of IDE chips with zeolite catalyst film (Figure 2b). A specially designed holder with electrical contacts was employed to keep the sensor chip inside the reaction chamber in a way that the zeolite film is in the focal point of the infrared beam of the DRIFTS mirror design. Simultaneous IS and DRIFTS measurements were carried out using the same catalyst film, allowing simultaneous monitoring of both the proton conductivity of zeolite catalysts and the vibration modes of the molecules on zeolite catalysts $[26,28]$. 


\section{Proton Transport in Zeolite Catalysts for $\mathrm{NH}_{3}-\mathrm{SCR}$}

\section{1. $\mathrm{NH}_{3}$-Supported Proton Transport}

Zeolites are a class of crystalline, microporous solids consisting of tetrahedral $\mathrm{TO}_{4}(\mathrm{~T}$ denotes as $\mathrm{Si}, \mathrm{Al}, \mathrm{Ti}$, etc.) units. The $\mathrm{TO}_{4}$ units serve as primary building blocks forming three-dimensional frameworks with interconnected cages and channels of distinct sizes and shapes. The Brønsted acidity of zeolites, which results from the non-equivalent substitution of T-atoms (e.g., the substitution of $\mathrm{Si}$ by $\mathrm{Al}$ in $\mathrm{TO}_{4}$ units as shown in Figure 3) and the subsequent charge-balancing by external, exchangeable cations $\left(\mathrm{Na}^{+}, \mathrm{NH}_{4}{ }^{+}, \mathrm{H}^{+}\right.$, etc.) at the adjacent oxygen sites within the pore space, enables several characteristic functions, such as ion-exchange capacity, proton donating ability and ionic conductivity $[3,40-42]$. These properties allow zeolites to be used as adsorbents, separators, ionic conductors, sensors, or catalysts [3,40-42].

i)

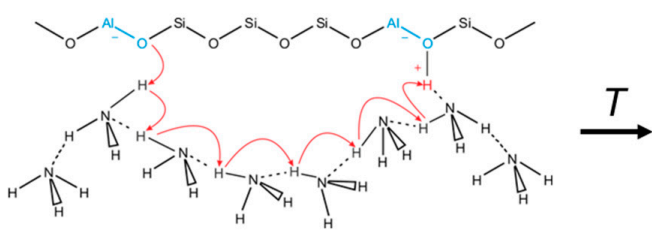

iv)

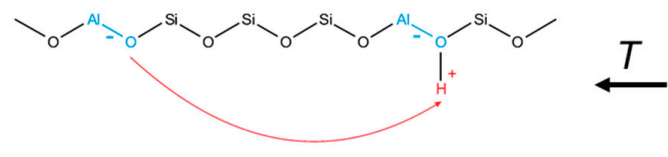

ii)

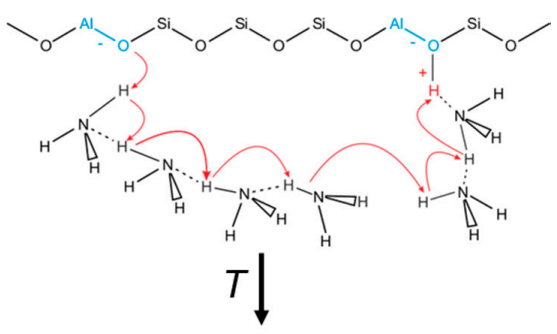

iii)

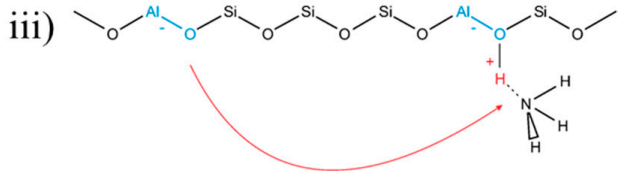

Figure 3. Schematic illustration of the mechanisms of proton transport occurring in $\mathrm{NH}_{3}$-loaded $\mathrm{H}$-form zeolites at different temperature ranges. (i) Grothuss-like proton transport along condensed $\mathrm{NH}_{3}$ molecules, i.e., $\mathrm{NH}_{4}{ }^{+} \cdot\left(\mathrm{NH}_{3}\right)_{n}$ chains (below $120^{\circ} \mathrm{C}$ ); (ii) proton transport along dis-integrated $\mathrm{NH}_{4}{ }^{+} \cdot\left(\mathrm{NH}_{3}\right)_{n}$ chains $\left(120-200^{\circ} \mathrm{C}\right)$; (iii) vehicle transport mechanism, where $\mathrm{NH}_{4}{ }^{+}$serves as "vehicle" like proton carrier $\left(200-340^{\circ} \mathrm{C}\right.$ ); and (iv) hopping transport of protons by thermal activation (above $340{ }^{\circ} \mathrm{C}$ ). Adapted with permission from [31]. Copyright American Chemical Society, 2016.

In $\mathrm{NH}_{3}$-SCR catalysis, protons on Brønsted acid sites of zeolite catalysts could transfer to adsorbed $\mathrm{NH}_{3}$ forming ammonium ions $\left(\mathrm{NH}_{4}{ }^{+}\right.$), which interact further with $\mathrm{NH}_{3}$ molecules leading to the formation of $\mathrm{NH}_{4}{ }^{+} \cdot\left(\mathrm{NH}_{3}\right)_{n}$ complexes at low temperatures [2]. Both $\mathrm{NH}_{4}{ }^{+}$and $\mathrm{NH}_{4}{ }^{+} \cdot\left(\mathrm{NH}_{3}\right)_{n}$ complexes can provide additional paths or carriers for proton transport, which consequently increase the proton conductivity of zeolite catalysts [26,32-34]. The physico-chemical features of $\mathrm{NH}_{3}$-supported proton transport were revealed by in situ studies over $\mathrm{NH}_{3}$-loaded zeolites using techniques combining IS with TPD or quantum chemical calculations [26-29,34,43], and are schematically illustrated in Figure 3 for proton-form zeolites. Four distinct temperature-dependent mechanisms can be distinguished, specifically (i) the Grothuss-like transport along condensed $\mathrm{NH}_{4}{ }^{+} \cdot\left(\mathrm{NH}_{3}\right)_{n}$ chains at low temperatures, i.e., below the desorption temperature of $\mathrm{NH}_{3}$; (ii) proton hopping along partially disintegrated chains of $\mathrm{NH}_{3}$ molecules (i.e., in the temperature range, where weakly bound solvent molecules desorb); (iii) vehicle-supported transfer of protons between the neighboring Brønsted sites with $\mathrm{NH}_{4}{ }^{+}$carriers as "proton vehicles"; and (iv) thermally activated proton hopping along the electron density located at the oxygen atoms of the zeolite lattice in the absence of solvate molecules (above $340^{\circ} \mathrm{C}$ ) $[26,32,33]$.

\subsection{Factors Influencing the Proton Transport in Zeolite Catalysts}

As can be seen in Figure 3, the proton transport in zeolites is largely determined by the abundance of Brønsted sites serving as the primary sites for the adsorption of $\mathrm{NH}_{3}$. This was already confirmed 
by our previous studies over ZSM-5 zeolites with different $\mathrm{Si} / \mathrm{Al}$ ratios [32,33]. For metal-exchanged zeolites used as catalysts in $\mathrm{NH}_{3}-\mathrm{SCR}$, several structural or chemical parameters such as framework topology, metal cation type, and metal exchange level also influence considerably the $\mathrm{NH}_{3}$-supported proton transport by affecting the formation of $\mathrm{NH}_{4}{ }^{+} \cdot\left(\mathrm{NH}_{3}\right)_{n}$ complexes and/or the affinity between the $\mathrm{NH}_{3}$ species and the zeolite catalysts.

\subsubsection{Metal Cation Type}

Based on the $\mathrm{NH}_{3}$-supported proton transport, the loading and desorption of $\mathrm{NH}_{3}$ in $\mathrm{Fe}$ - and Cu-ZSM-5 can be effectively monitored by means of in situ IS (Figure 4a). Comparative studies revealed that, as compared to Fe-ZSM-5, the Cu-ZSM-5 demonstrated a stronger retention ability against thermal desorption for the adsorbed $\mathrm{NH}_{3}$ species (i.e., $\mathrm{NH}_{4}{ }^{+}$on Brønsted as indicated by the IR band at $1457 \mathrm{~cm}^{-1}$, and the $\mathrm{NH}_{3}$ on metal sites as indicated by the IR band at 1276/1266 $\mathrm{cm}^{-1}$ ), which is due to a stronger $\mathrm{NH}_{3}$-zeolite interaction (according to the higher activation energy $E_{\mathrm{a}}$ for proton transport by multi-frequency IS experiments; see Figure $4 \mathrm{~b}$ ). During exposure in $\mathrm{NO} / \mathrm{O}_{2}$ mixture for the SCR conversion of stored $\mathrm{NH}_{3}$ (Figure 5), while the proton conductivity of $\mathrm{NH}_{3}$-saturated Fe-ZSM-5 decreased rapidly, that of $\mathrm{NH}_{3}$-saturated Cu-ZSM-5 increased further significantly (Figure 5a). Such unexpected increase of proton conductivity during $\mathrm{NO} / \mathrm{O}_{2}$ exposure was observed in the temperature range of $100-250{ }^{\circ} \mathrm{C}$ over $\mathrm{NH}_{3}$-saturated $\mathrm{Cu}-\mathrm{ZSM}-5$ (Figure 6a). In situ IS-DRIFTS studies revealed that the increased proton conductivity results mainly from $\mathrm{NH}_{4}{ }^{+}$ intermediates (Figure $6 \mathrm{~b}$ ), which formed via the following route: (i) interaction of $\mathrm{NO}$ and adsorbed $\mathrm{NH}_{3}$ on $\mathrm{Cu}^{2+}$ sites; (ii) reduction of $\mathrm{Cu}^{2+}$ to $\mathrm{Cu}^{+}$and release of a proton on the adjacent Brønsted site (i.e., $\mathrm{Cu}^{2+} \rightarrow \mathrm{Cu}^{+}+\mathrm{H}^{+}$); and (iii) interaction of the released proton and adsorbed $\mathrm{NH}_{3}$ on $\mathrm{Cu}$ sites (i.e., $\mathrm{H}^{+}+\mathrm{NH}_{3} \rightarrow \mathrm{NH}_{4}^{+}$) $[27,29,44,45]$. The enhanced proton transport of $\mathrm{NH}_{3}$-saturated zeolite catalysts by $\mathrm{NO}$ exposure is thus considered to manifest the $\mathrm{NO}$ activation ability in the presence of adsorbed $\mathrm{NH}_{3}$ [29].

a)

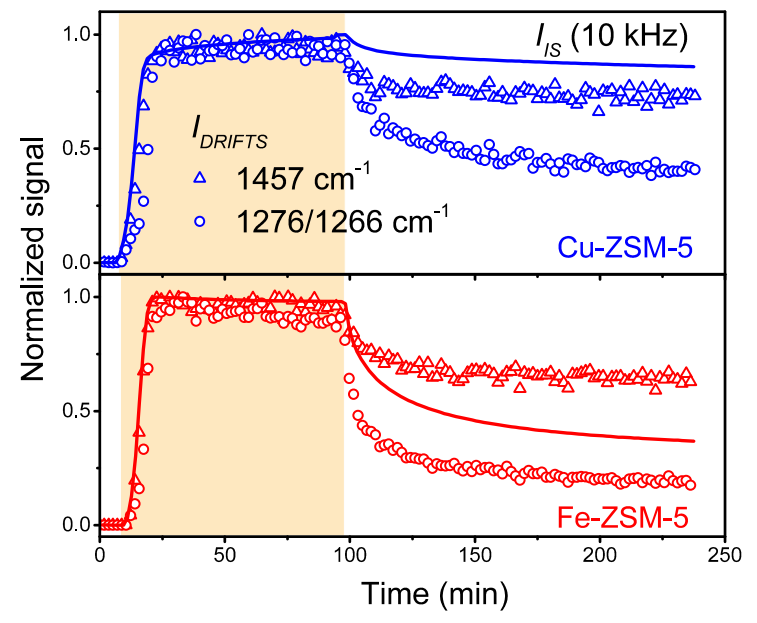

b)

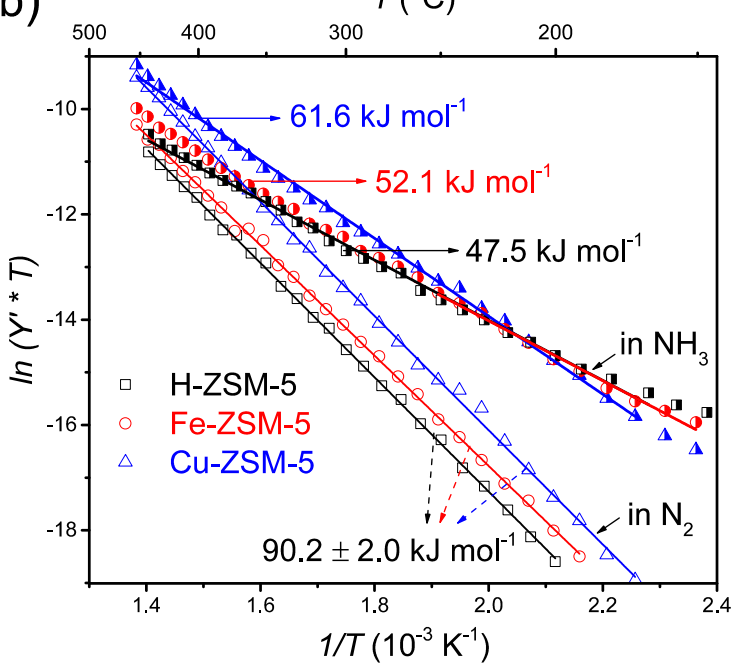

Figure 4. (a) simultaneously measured proton conductivity ( $I_{\mathrm{IS}}$; IS signal at $10 \mathrm{kHz}$; solid lines) and

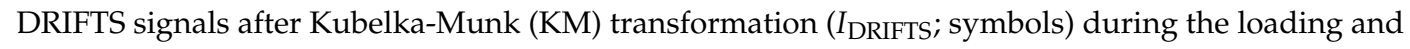
thermal desorption of $\mathrm{NH}_{3}$ over zeolites at $100^{\circ} \mathrm{C}$. The colorful background indicates the period with $\mathrm{NH}_{3}$ supply to the system. I DRIFTS at $1457 \mathrm{~cm}^{-1}$ (triangles) and $1276 / 1266 \mathrm{~cm}^{-1}$ (circles) are attributed to the bending vibrations of $\mathrm{NH}_{4}{ }^{+}$ions on Brønsted acid sites and bending vibrations of $\mathrm{NH}_{3}$ species on metal sites, respectively; and (b) Arrhenius-like representations for the IS results obtained in flowing $\mathrm{N}_{2}$ (empty symbols) and $\mathrm{NH}_{3}$ (100 ppm in $\mathrm{N}_{2}$; half-filled symbols) over H-ZSM-5 (squares), Fe-ZSM-5 (circles) and Cu-ZSM-5 (triangles). Reproduced with permission from [29]. Copyright The Royal Society of Chemistry, 2016. 
a)

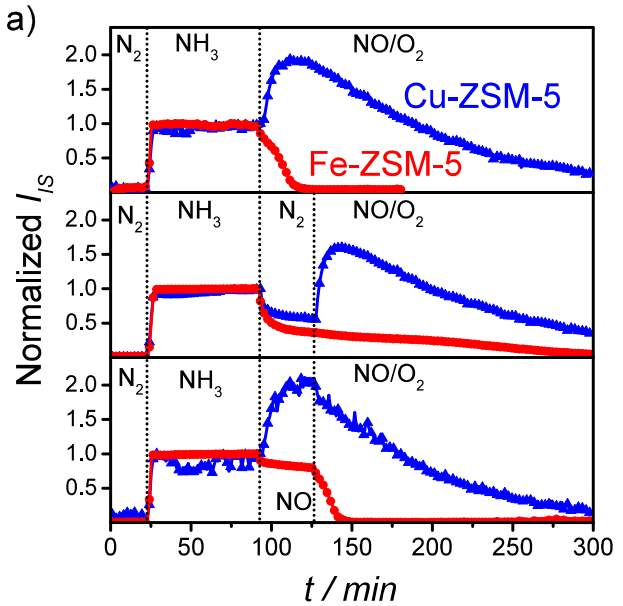

b)

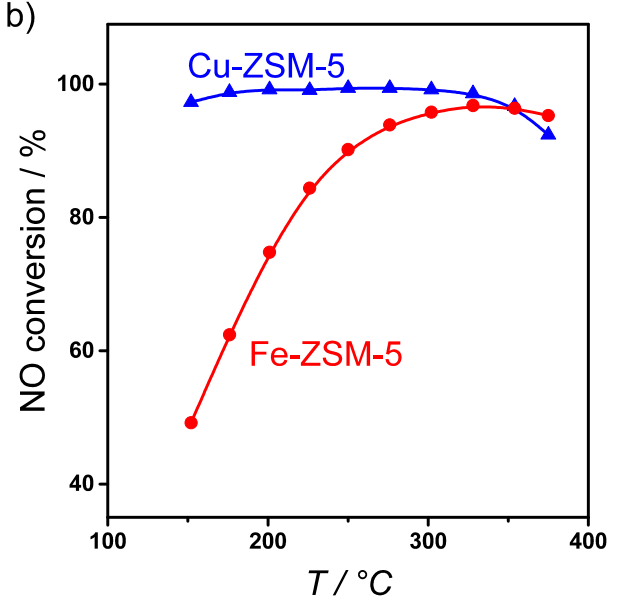

Figure 5. (a) time-courses of normalized proton conductivity $I_{\text {IS }}$ (at $10 \mathrm{kHz}$ ) for Fe-ZSM-5 and $\mathrm{Cu}$-ZSM-5 during exposure to the indicated atmospheres at $175^{\circ} \mathrm{C} ;(\mathbf{b})$ measured $\mathrm{NO}$ conversion in selective catalytic reduction ( $\mathrm{NH}_{3}-\mathrm{SCR}$ ) over Fe-ZSM- 5 and Cu-ZSM-5 ( $0.5 \mathrm{~g}$ catalyst; a total flow rate of $1 \mathrm{~L} \cdot \mathrm{min}^{-1} ; 500 \mathrm{ppm} \mathrm{NH}, 500 \mathrm{ppm} \mathrm{NO}, 10 \% \mathrm{O}_{2}, 2 \% \mathrm{H}_{2} \mathrm{O}$ ). Reproduced with permission from [29]. Copyright The Royal Society of Chemistry, 2016.
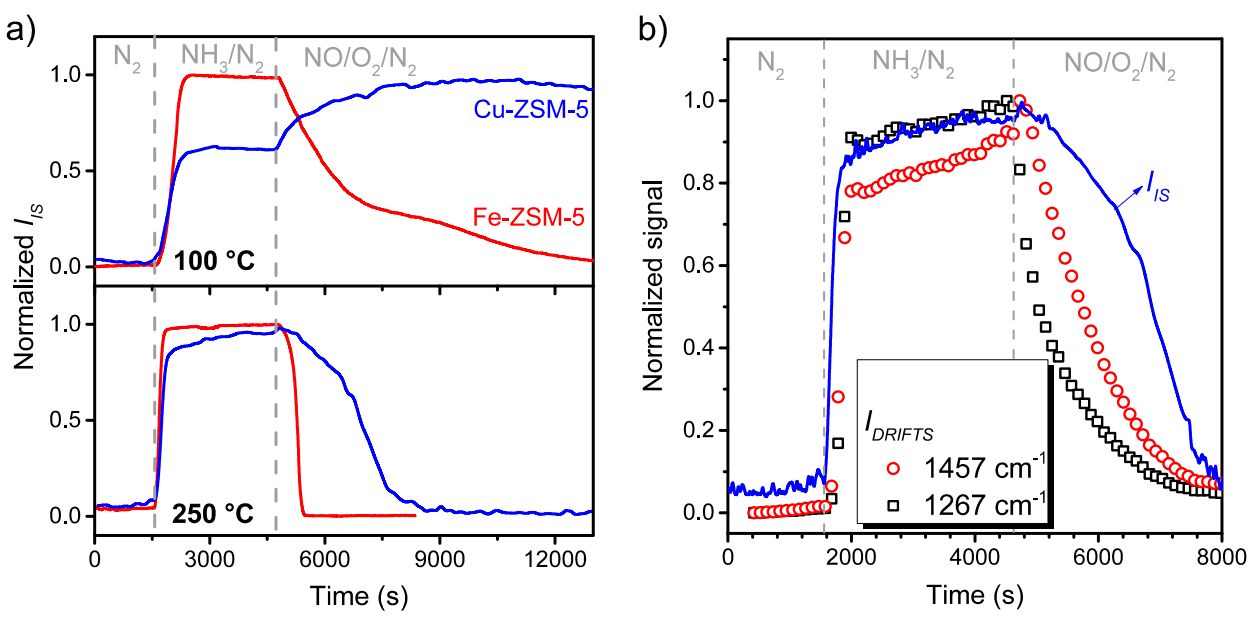

Figure 6. (a) time-courses of normalized proton conductivity $I_{\text {IS }}$ (at $10 \mathrm{kHz}$ ) for Fe-ZSM-5 and $\mathrm{Cu}$-ZSM-5 during exposure to the indicated atmospheres at $100^{\circ} \mathrm{C}$ and $250^{\circ} \mathrm{C} ;(\mathbf{b})$ normalized I (line)

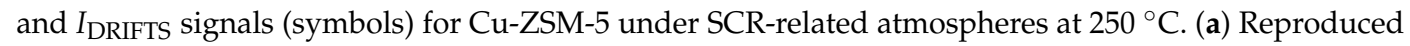
with permission from [29]. Copyright The Royal Society of Chemistry, 2016; (b) Reprinted with permission from [31]. Copyright American Chemical Society, 2016.

It has to be noted that the redox cycle of active metal sites consists of a reduction half-cycle $\left(\mathrm{Cu}^{2+} \rightarrow \mathrm{Cu}^{+}\right.$or $\left.\mathrm{Fe}^{3+} \rightarrow \mathrm{Fe}^{2+}\right)$ and a re-oxidation half-cycle $\left(\mathrm{Cu}^{+} \rightarrow \mathrm{Cu}^{2+}\right.$ or $\left.\mathrm{Fe}^{2+} \rightarrow \mathrm{Fe}^{3+}\right)$, and the latter one is usually considered to be the rate-determining step in the whole redox processes $[10,11]$. Therefore, further IS studies on the re-oxidation half-cycle are needed to understand in more detail the very different low-temperature $\mathrm{NH}_{3}$-SCR activities of $\mathrm{Cu}$ - and Fe-exchanged zeolite catalysts (Figure 5b) [29].

\subsubsection{Metal Exchange Level}

The metal exchange level (estimated according to, for example, the metal to Al ratio in metal-exchange aluminosilicate zeolites) of zeolite catalyst is known to have a strong impact in $\mathrm{NH}_{3}$-SCR catalysis [46-50]. In the case of ZSM-5 with a Si/ $\mathrm{Al}$ ratio of 13.5, while the $\mathrm{Cu}$ species in 
$\mathrm{Cu}-\mathrm{ZSM}-5$ remain mainly in isolated state at a $\mathrm{Cu} / \mathrm{Al}$ ratio of ca. 0.2 , a considerable amount of $\mathrm{Fe}$ dimers or oligomers form in Fe-ZSM- 5 with a Fe/ Al ratio of ca. 0.2 and above [31]. The introduced metal species can adsorb $\mathrm{NH}_{3}$ at an intermediate strength (stronger than the adsorption on Lewis sites, but weaker than that on Brønsted sites), as characterized by the $\mathrm{NH}_{3}$ desorption at temperatures between 130 and $250{ }^{\circ} \mathrm{C}$ (Figure 7a) [7]. The influence of metal exchange level on the $\mathrm{NH}_{3}$-zeolite interaction can be examined by analyzing the mobility of adsorbed $\mathrm{NH}_{3}$-species as proton carriers under thermal desorption conditions by means of in situ IS [31]. As indicated by the activation energies for proton transport (i.e., the strength of $\mathrm{NH}_{3}$ adsorption on zeolites), while the increase of $\mathrm{Fe}$ loading weakened slightly the $\mathrm{NH}_{3}$-zeolite interaction, a higher $\mathrm{Cu}$ loading enhanced significantly the $\mathrm{NH}_{3}$-zeolite interaction (Figure $7 \mathrm{~b}$ ). The weakening interaction between $\mathrm{NH}_{3}$ and Fe-ZSM- 5 with increasing $\mathrm{Fe} / \mathrm{Al}$ ratio can be clearly visualized in DRIFTS (Figure 7c), according to the decreasing band intensity at $1266 \mathrm{~cm}^{-1}$ originating from the $\mathrm{NH}_{3}$ species on Fe sites [17,31]. $\mathrm{In} \mathrm{NH}_{3}$-SCR catalysis, for the zeolite catalysts shown in Figure $7 \mathrm{~b}$, while the low-temperature (below $250{ }^{\circ} \mathrm{C}$ ) $\mathrm{NH}_{3}-\mathrm{SCR}$ activity of Fe-ZSM-5 decreased with $\mathrm{Fe} / \mathrm{Al}$ ratio, that of $\mathrm{Cu}-\mathrm{ZSM}-5$ increased with $\mathrm{Cu} / \mathrm{Al}$ ratio $[17,31]$.
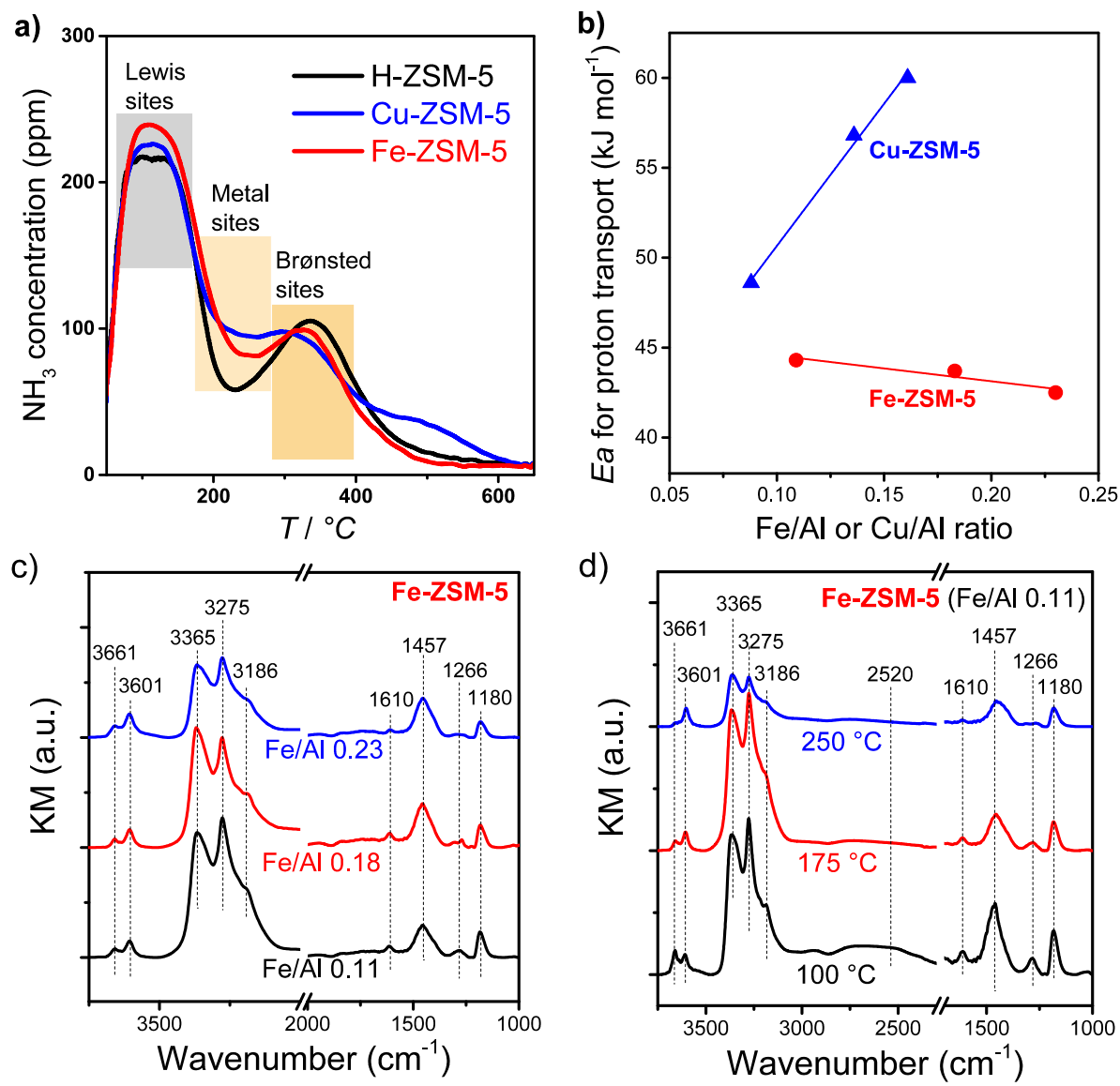

Figure 7. (a) $\mathrm{NH}_{3}$-TPD (temperature-programmed desorption using $\mathrm{NH}_{3}$ as a probe molecule) profiles showing the desorption of $\mathrm{NH}_{3}$ species on Lewis sites, metal sites and Brønsted sites in different temperature ranges; $(\mathbf{b})$ activation energy $\left(E_{\mathrm{a}}\right)$ for proton transport as a function of metal exchange level. The $E_{\mathrm{a}}$ values were derived from the Arrhenius plots of the in situ IS results over $\mathrm{NH}_{3}$-loaded zeolite catalysts under thermal desorption conditions (in $\mathrm{N}_{2}$ ) at temperatures $130-250{ }^{\circ} \mathrm{C}$; (c) in situ DRIFT spectra for $\mathrm{NH}_{3}$-saturated $\mathrm{Fe}-\mathrm{ZSM}-5$ zeolite catalysts with different $\mathrm{Fe} / \mathrm{Al}$ ratios at $175{ }^{\circ} \mathrm{C}$; (d) in situ DRIFT spectra for a $\mathrm{NH}_{3}$-saturated Fe-ZSM-5 zeolite catalyst (Fe/ $\mathrm{Al}$ ratio of 0.11 ) at different temperatures. (a) Reproduced with permission from [29]. Copyright The Royal Society of Chemistry, 2016; (b) Reprinted with permission from [31], American Chemical Society, 2016; (c,d) Reprinted with permission from [17]. Copyright American Chemical Society, 2016. 
At high Fe loadings or under harsh conditions (e.g., hydrothermal aging), the Fe species in Fe-zeolites may aggregate forming $\mathrm{Fe}_{\mathrm{x}} \mathrm{O}_{\mathrm{y}}$ dimers or small clusters within the zeolite pores, or even relatively large $\mathrm{Fe}_{2} \mathrm{O}_{3}$ particles outside the zeolite pores [31]. At low temperatures, these $\mathrm{Fe}_{x} \mathrm{O}_{y}$ species or $\mathrm{Fe}_{2} \mathrm{O}_{3}$ particles could provide additional acidic sites for the adsorption of $\mathrm{NH}_{3}$ species, favoring the formation of $\mathrm{NH}_{4}{ }^{+} \cdot\left(\mathrm{NH}_{3}\right)_{n}$ chains (as indicated by the broad band centered at ca. $2520 \mathrm{~cm}^{-1}$ in the DRIFT spectra in Figure 7d) and consequently the proton transport within the zeolite lattice [28,29]. At high temperatures $\left(175^{\circ} \mathrm{C}\right.$ and above), however, the weakly bound $\mathrm{NH}_{3}$ species cannot be retained on the $\mathrm{Fe}_{x} \mathrm{O}_{y}$ species or $\mathrm{Fe}_{2} \mathrm{O}_{3}$ particles (as indicated by the disappearance of the broad band centered at ca. $2520 \mathrm{~cm}^{-1}$ ) and thus have no (or just negligible) contribution to the proton transport $[17,29]$.

\subsubsection{Zeolite Framework Type}

Among different zeolite framework types, those with medium or small pore diameters (such as CHA, MFI, MOR, FER, etc.) after metal ion exchange were found to be especially advantageous for $\mathrm{NH}_{3}-\mathrm{SCR}$ catalysis [2-4]. A comparison of Cu-ZSM-5 (MFI type) and Cu-SAPO-34 (CHA type) zeolites using in situ IS revealed that the framework type influenced significantly the proton transport properties of $\mathrm{Cu}$-zeolite catalysts under $\mathrm{NH}_{3}-\mathrm{SCR}$ related conditions [27]. At low temperatures, formation of highly proton-conducting $\mathrm{NH}_{4}{ }^{+}$intermediates was observed in both zeolites (Figures $6 \mathrm{~b}$ and 8), which is due to the reduction of $\mathrm{Cu}^{2+}$ to $\mathrm{Cu}^{+}$as a result of the interaction of $\mathrm{NH}_{3}$ and $\mathrm{NO}[17,25,29,44]$. In the monitoring of $\mathrm{NH}_{3}-\mathrm{SCR}$ using the zeolite catalysts directly as sensors, while the performance of Cu-SAPO-34 can be improved by increasing the temperature to $200{ }^{\circ} \mathrm{C}$ and above, that of Cu-ZSM-5 was impeded by the formation of $\mathrm{NH}_{4}{ }^{+}$intermediates even at high temperatures as $350{ }^{\circ} \mathrm{C}$ (Figure 9). Both zeolites performed similarly in the direct monitoring of $\mathrm{NH}_{3}-\mathrm{SCR}$ at temperatures above $350{ }^{\circ} \mathrm{C}$. At $200{ }^{\circ} \mathrm{C}$ and below, Cu-SAPO-34 also showed higher $\mathrm{NH}_{3}$-SCR activity than $\mathrm{Cu}-\mathrm{ZSM}-5$ [27]. The difference in proton transport, $\mathrm{NH}_{3}-\mathrm{SCR}$ reaction monitoring and $\mathrm{NH}_{3}-\mathrm{SCR}$ catalysis can be attributed to the different coordinative nature of the metal sites in the two catalysts [4]. Systematic investigations are required to gain more insights into this issue.

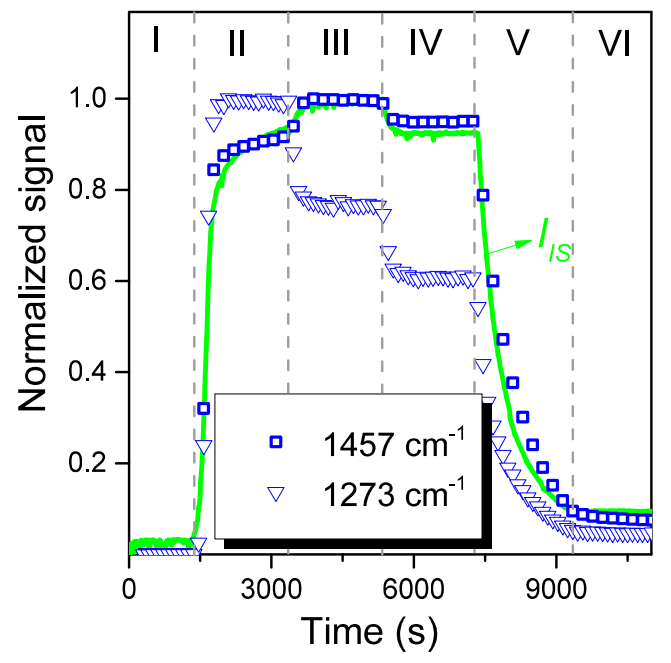

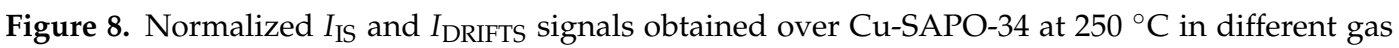
mixtures; (I) pure $\mathrm{N}_{2}$; (II) 100 ppm $\mathrm{NH}_{3}, \mathrm{~N}_{2}$ balance; (III) 70 ppm NH 3,20 ppm NO, 10\% $\mathrm{O}_{2}, \mathrm{~N}_{2}$ balance; (IV) 45 ppm NH 3,45 ppm NO, 10\% $\mathrm{O}_{2}, \mathrm{~N}_{2}$ balance; (V) 20 ppm NH, 70 ppm NO, 10\% $\mathrm{O}_{2}$, $\mathrm{N}_{2}$ balance; (VI) 100 ppm NO, $\mathrm{N}_{2}$ balance. Cu-SAPO-34: $1 \mathrm{wt} \% \mathrm{Cu},(\mathrm{P}+\mathrm{Al}) / \mathrm{Si}=12.9 .1457 \mathrm{~cm}^{-1}$ : $\mathrm{NH}_{4}{ }^{+}$ions on Brønsted acid sites; $1273 \mathrm{~cm}^{-1}: \mathrm{NH}_{3}$ species on $\mathrm{Cu}$ sites. Reproduced with permission from [25]. 


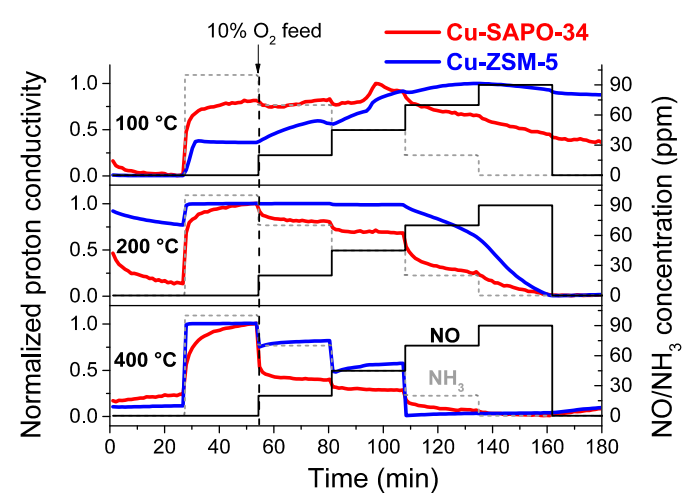

Figure 9. Electric signals of Cu-ZSM-5 and Cu-SAPO-34 in SCR-related atmospheres. Cu-SAPO-34: 1 wt \% Cu, $(\mathrm{P}+\mathrm{Al}) / \mathrm{Si}=12.9 . \mathrm{Cu}-\mathrm{ZSM}-5: 1 \mathrm{wt} \% \mathrm{Cu}, \mathrm{Si} / \mathrm{Al}=13.5$. Reproduced with permission from [27]. Copyright Elsevier, 2016.

\subsubsection{Formation of $\mathrm{NH}_{4}{ }^{+}$Intermediates}

In zeolite catalyzed $\mathrm{NH}_{3}-\mathrm{SCR}$ reactions, depending on the used catalysts and reaction conditions, different intermediate species, such as $\mathrm{NO}^{+}$[51], $\mathrm{NO}_{3}{ }^{-}$[45], $\mathrm{NO}_{2}{ }^{-}$[52], $\mathrm{H}^{+}$[11], $\mathrm{NH}_{4}{ }^{+}$[44], have been observed forming. As shown in Figures $6 \mathrm{~b}$ and 8, highly mobile $\mathrm{NH}_{4}{ }^{+}$intermediates formed on $\mathrm{Cu}-\mathrm{ZSM}-5$ and $\mathrm{Cu}-\mathrm{SAPO}-34$ as a result of the $\mathrm{NH}_{3}-\mathrm{NO}$ interaction [44]. In case of Fe-ZSM-5, due to the well-known $\mathrm{NH}_{3}$-inhibition effect [10,53], formation of $\mathrm{NH}_{4}{ }^{+}$intermediates (resulting from the reduction of $\mathrm{Fe}^{3+}$ to $\mathrm{Fe}^{2+}$ similar as the $\mathrm{Cu}$ redox cycle) at low reaction temperatures can only be clearly observed by in situ IS-DRIFTS after a partial desorption of adsorbed $\mathrm{NH}_{3}$ (Figure 10a) [17]. Nevertheless, adsorption and activation of $\mathrm{NO}$ did take place on $\mathrm{NH}_{3}$-satured Fe-ZSM-5, leading to the formation of $\mathrm{NH}_{4}{ }^{+}$intermediates, clearly enhancing the proton conductivity of $\mathrm{NH}_{3}$-loaded Fe-ZSM-5 in $\mathrm{NO}$ (see the higher $I_{I S}$ values during exposure in NO than in $\mathrm{N}_{2}$; Figure 10b). These observations indicate a $\mathrm{Fe}^{3+} \leftrightarrow \mathrm{Fe}^{2+}$ redox cycle in Fe-ZSM-5 catalysts similar as the widely accepted $\mathrm{Cu}^{2+} \leftrightarrow \mathrm{Cu}^{+}$ redox cycle in Cu-SSZ-13 catalysts (Figure 11a) [3,10,11,44,45,54]. More interestingly, the formed $\mathrm{NH}_{4}{ }^{+}$ intermediates were found to largely determine the $\mathrm{NH}_{3}$-SCR activity of Fe-ZSM- 5 catalysts at low temperatures (Figure 11b). Therefore, the formation of $\mathrm{NH}_{4}{ }^{+}$intermediates, indicating the activation of $\mathrm{NO}$ in the presence of adsorbed $\mathrm{NH}_{3}$, may potentially serve as a 'descriptor' of the activity of Fe-zeolite catalyst for $\mathrm{NH}_{3}-\mathrm{SCR}$, especially at low temperatures.
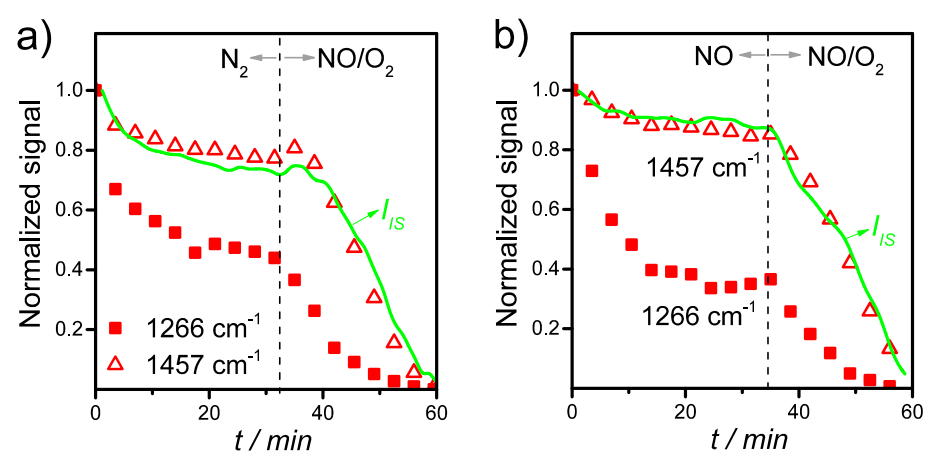

Figure 10. Normalized $I_{\text {IS }}$ (green line) and DRIFTS signals (red symbols) at characteristic wavenumbers of $\mathrm{NH}_{3}$-loaded Fe-ZSM-5 (Si/ $\mathrm{Al} 13.5, \mathrm{Fe} / \mathrm{Al}$ 0.11) exposed $\mathrm{N}_{2}$ and $\mathrm{NO} / \mathrm{O}_{2}$ mixture in sequence (a) and exposed to $\mathrm{NO}$ and $\mathrm{NO} / \mathrm{O}_{2}$ mixture in sequence $(\mathbf{b})$. IIS: absolute value of complex admittance $\left|Y^{*}\right|$ ( $Y^{*}$ is the reciprocal of the complex impedance $Z^{*}$, i.e., $Y^{*}=1 / Z^{*}$ ) at $10 \mathrm{kHz} .1457 \mathrm{~cm}^{-1}: \mathrm{NH}_{4}{ }^{+}$ions on Brønsted acid sites; $1266 \mathrm{~cm}^{-1}: \mathrm{NH}_{3}$ species on Fe sites. The catalyst was pre-treated at $450{ }^{\circ} \mathrm{C}$ in $10 \% \mathrm{O}_{2}$ for $1 \mathrm{~h}$ before each measurement. Reprinted with permission from [17]. Copyright American Chemical Society, 2016. 
(a)

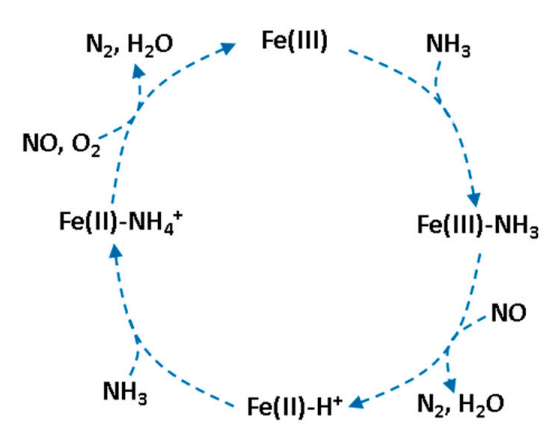

(b)

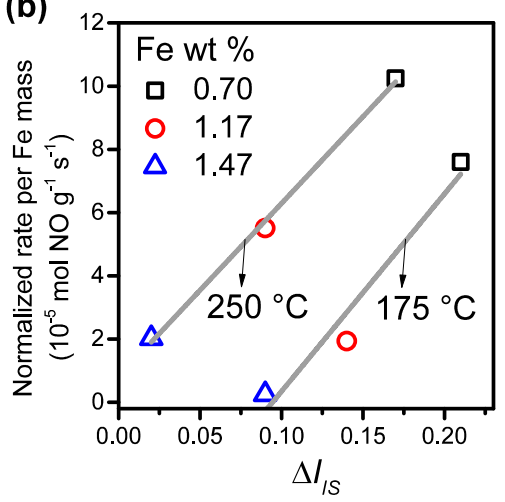

Figure 11. (a) proposed pathway for the formation of $\mathrm{NH}_{4}{ }^{+}$intermediate in $\mathrm{NH}_{3}-\mathrm{SCR}$ over Fe-ZSM-5 catalysts; (b) correlation between the $\mathrm{NH}_{4}{ }^{+}$intermediate formation and the normalized $\mathrm{NO}$ reduction rates at low temperatures; the $\mathrm{NH}_{4}{ }^{+}$intermediate formation $\left(\Delta I_{\mathrm{IS}}\right)$ was evaluated according to the proton conductivity enhancement of $\mathrm{NH}_{3}$-loaded Fe-ZSM- 5 after exposure in NO for 30 min in comparison to exposure in $\mathrm{N}_{2}$ for 30 min. Reprinted with permission from [17]. Copyright American Chemical Society, 2016.

\subsection{5. $\mathrm{H}_{2} \mathrm{O}$ Vapor}

In real diesel exhausts, a considerable amount of $\mathrm{H}_{2} \mathrm{O}$ vapor resulting from the fuel combustion processes and the $\mathrm{NH}_{3}-\mathrm{SCR}$ reactions is always present. As revealed previously, $\mathrm{H}_{2} \mathrm{O}$ as a solvate molecule could serve as proton carrier as well and consequently enhance the proton conductivity of zeolites in a broad temperature range [33]. As compared to $\mathrm{NH}_{3}, \mathrm{H}_{2} \mathrm{O}$ demonstrates a significantly weaker supporting effect for the proton transport in zeolites [16], specifically, 1 vol. \% $\mathrm{H}_{2} \mathrm{O}$ vapor only has the same effect as $6 \mathrm{ppm}$ of $\mathrm{NH}_{3}$ in terms of the conductivity change of H-ZSM-5 (at $420{ }^{\circ} \mathrm{C}$ ) [55]. In the above-mentioned transient IS measurements (in the absence of $\mathrm{H}_{2} \mathrm{O}$ ), a significant influence of $\mathrm{H}_{2} \mathrm{O}$ as the product of $\mathrm{NH}_{3}$-SCR reaction can thus be ruled out because of the very low concentration. Nevertheless, minor contribution of $\mathrm{H}_{2} \mathrm{O}$ to the overall proton conductivity of the respective zeolite catalyst cannot be fully excluded. Further comparative studies (with or without $\mathrm{H}_{2} \mathrm{O}$ ) are required to achieve a more complete understanding of the influence of $\mathrm{H}_{2} \mathrm{O}$.

\subsubsection{Zeolite Crystallite Size}

Although the crystallite size of zeolite was found to influence limitedly the intrinsic $\mathrm{NH}_{3}$-SCR activities of metal-exchanged zeolite catalysts (e.g., Cu-SSZ-13, Cu-SAPO-34, Fe-ZSM-5) [56-58], a decrease of crystal size from several micrometers to $50-100 \mathrm{~nm}$ can improve the hydrothermal stability of zeolite catalysts [56,57]. For proton transport in zeolites, the influence of crystallite size (or grain boundary) is negligible with crystallite size at micrometer level, and is noted only with crystallite sizes below $200 \mathrm{~nm}$ [59]. Considering that commercially relevant zeolite materials with a broad distribution of crystallite size $(0.5-5 \mu \mathrm{m})$ were applied in the above-mentioned IS studies $[17,25-36]$, a noticeable influence of the zeolite crystallite size can be excluded.

\section{Summary and Perspectives}

In summary, by analyzing the proton transport properties of zeolite catalysts under SCR-related reaction conditions using in situ IS, the $\mathrm{NH}_{3}$-zeolite interaction, NO-zeolite interaction (in the presence of adsorbed $\mathrm{NH}_{3}$ ), and formation of proton-conducting intermediates can be probed. A combination of IS with DRIFTS allows for understanding molecularly the proton transport properties of zeolite $\mathrm{NH}_{3}$-SCR catalysts. Several structural or chemical parameters, such as framework topology, metal cation type and metal exchange level, influenced the proton transport to different degrees by affecting the reactant-zeolite interactions. On the one hand, the mobility of adsorbed $\mathrm{NH}_{3}$-species as proton 
carriers, determined by the $\mathrm{NH}_{3}$-zeolite interaction, was influenced differently by the type, loading and coordinative environment of the exchanged $\mathrm{Fe}$ or $\mathrm{Cu}$ species in zeolite catalysts. On the other hand, highly mobile $\mathrm{NH}_{4}{ }^{+}$intermediates, as identified by IS combined with DRIFTS, can form on zeolite catalysts as general intermediate species resulting from the interaction of co-adsorbed $\mathrm{NH}_{3}$ and $\mathrm{NO}$ on metal active sites. The formed $\mathrm{NH}_{4}{ }^{+}$intermediates not only significantly influenced the proton transport properties, and consequently the reaction monitoring performance of zeolite catalysts due to the highly proton-conducting nature, but also largely determined the low-temperature $\mathrm{NH}_{3}-\mathrm{SCR}$ activity because of their high mobility and reactivity. These findings, which are not easily achievable by conventional methods, thus provide new perspectives to understand mechanistically the $\mathrm{NH}_{3}-\mathrm{SCR}$ reaction over zeolite catalysts.

To understand further the role of proton transport in $\mathrm{NH}_{3}-\mathrm{SCR}$ catalysis, both chemical nature (e.g., surface acidity, chemical composition) and structural properties (e.g., size, shape, or porosity) of the zeolite catalysts should be taken into account. Substantial improvements, for example the synthesis of zeolites with well-controlled crystal sizes or porosity, have already been achieved using delicately designed bottom-up (i.e., controlling the chemical and structural properties by adjusting the synthetic procedure) or top-down (i.e., post-synthetic modifications) approaches $[60,61]$. Although the electrical and catalytic properties of zeolites can be correlated to certain specific chemical or structural features in a collective manner, it is still practically challenging to discriminate intrinsic and interfacial effects in the mentioned applications. In recent years, several advanced techniques, such as X-ray based micro-spectroscopy or local-probe measurement, have been developed to analyze in situ the chemical nature, the three-dimensional structure, the electrical properties, and eventually the structure-activity relationship at single-particle levels without the interference of boundary effects $[15,62,63]$. It is expected that a combination of these new techniques will promote achieving more reliable guidelines for the rational development of zeolite catalysts in the future.

Acknowledgments: We appreciate the funding from the German Research Foundation (DFG) under grant SI 609/14-1, and from the Exploratory Research Space of RWTH Aachen University financed by the Excellence Initiative of the German federal and state governments to promote science and research at German universities.

Author Contributions: P.C. and U.S. wrote the draft and improved the manuscript based on the reviewers' comments.

Conflicts of Interest: The authors declare no conflict of interest.

\section{References}

1. Granger, P.; Parvulescu, V.I. Catalytic $\mathrm{NO}_{x}$ Abatement Systems for Mobile Sources: From Three-Way to Lean Burn after-Treatment Technologies. Chem. Rev. 2011, 111, 3155-3207. [CrossRef] [PubMed]

2. Brandenberger, S.; Kröcher, O.; Tissler, A.; Althoff, R. The State of the Art in Selective Catalytic Reduction of $\mathrm{NO}_{x}$ by Ammonia Using Metal-Exchanged Zeolite Catalysts. Catal. Rev. 2008, 50, 492-531. [CrossRef]

3. Beale, A.M.; Gao, F.; Lezcano-Gonzalez, I.; Peden, C.H.F.; Szanyi, J. Recent Advances in Automotive Catalysis for $\mathrm{NO}_{x}$ Emission Control by Small-Pore Microporous Materials. Chem. Soc. Rev. 2015, 44, 7371-7405. [CrossRef] [PubMed]

4. Deka, U.; Lezcano-Gonzalez, I.; Weckhuysen, B.M.; Beale, A.M. Local Environment and Nature of Cu Active Sites in Zeolite-Based Catalysts for the Selective Catalytic Reduction of $\mathrm{NO}_{x}$. ACS Catal. 2013, 3, $413-427$. [CrossRef]

5. Yu, T.; Hao, T.; Fan, D.; Wang, J.; Shen, M.; Li, W. Recent $\mathrm{NH}_{3}$-SCR Mechanism Research over Cu/SAPO-34 Catalyst. J. Phys. Chem. C 2014, 118, 6565-6575. [CrossRef]

6. Li, Y.; Deng, J.; Song, W.; Liu, J.; Zhao, Z.; Gao, M.; Wei, Y.; Zhao, L. Nature of Cu Species in Cu-SAPO-18 Catalyst for $\mathrm{NH}_{3}-\mathrm{SCR}$ : Combination of Experiments and DFT Calculations. J. Phys. Chem. C 2016, 120, 14669-14680. [CrossRef]

7. Lezcano-Gonzalez, I.; Deka, U.; Arstad, B.; Van Yperen-De Deyne, A.; Hemelsoet, K.; Waroquier, M.; Van Speybroeck, V.; Weckhuysen, B.M.; Beale, A.M. Determining the Storage, Availability and Reactivity of $\mathrm{NH}_{3}$ within Cu-Chabazite-based Ammonia Selective Catalytic Reduction Systems. Phys. Chem. Chem. Phys. 2014, 16, 1639-1650. [CrossRef] [PubMed] 
8. Brandenberger, S.; Kröcher, O.; Wokaun, A.; Tissler, A.; Althoff, R. The Role of Brønsted Acidity in the Selective Catalytic Reduction of NO with Ammonia over Fe-ZSM-5. J. Catal. 2009, 268, 297-306. [CrossRef]

9. Maier, S.M.; Jentys, A.; Janousch, M.; van Bokhoven, J.A.; Lercher, J.A. Unique Dynamic Changes of Fe Cationic Species under $\mathrm{NH}_{3}$-SCR Conditions. J. Phys. Chem. C 2012, 116, 5846-5856. [CrossRef]

10. Boubnov, A.; Carvalho, H.W.; Doronkin, D.E.; Gunter, T.; Gallo, E.; Atkins, A.J.; Jacob, C.R.; Grunwaldt, J.D. Selective Catalytic Reduction of NO over Fe-ZSM-5: Mechanistic Insights by Operando HERFD-XANES and Valence-to-core X-ray Emission Spectroscopy. J. Am. Chem. Soc. 2014, 136, 13006-13015. [CrossRef] [PubMed]

11. Paolucci, C.; Parekh, A.A.; Khurana, I.; Di Iorio, J.R.; Li, H.; Albarracin Caballero, J.D.; Shih, A.J.; Anggara, T.; Delgass, W.N.; Miller, J.T.; et al. Catalysis in a Cage: Condition-Dependent Speciation and Dynamics of Exchanged Cu Cations in SSZ-13 Zeolites. J. Am. Chem. Soc. 2016, 138, 6028-6048. [CrossRef] [PubMed]

12. Moreno-González, M.; Hueso, B.; Boronat, M.; Blasco, T.; Corma, A. Ammonia-Containing Species Formed in Cu-Chabazite As Per In Situ EPR, Solid-State NMR, and DFT Calculations. J. Phys. Chem. Lett. 2015, 6, 1011-1017. [CrossRef] [PubMed]

13. Borfecchia, E.; Lomachenko, K.A.; Giordanino, F.; Falsig, H.; Beato, P.; Soldatov, A.V.; Bordiga, S.; Lamberti, C. Revisiting the Nature of $\mathrm{Cu}$ Sites in the Activated Cu-SSZ-13 Catalyst for SCR Reaction. Chem. Sci. 2015, 6, 548-563. [CrossRef]

14. Svelle, S.; Tuma, C.; Rozanska, X.; Kerber, T.; Sauer, J. Quantum Chemical Modeling of Zeolite-catalyzed Methylation Reactions: Toward Chemical Accuracy for Barriers. J. Am. Chem. Soc. 2009, 131, 816-825. [CrossRef] [PubMed]

15. Vogt, E.T.; Weckhuysen, B.M. Fluid Catalytic Cracking: Recent Developments on the Grand Old Lady of Zeolite Catalysis. Chem. Soc. Rev. 2015, 44, 7342-7370. [CrossRef] [PubMed]

16. Sauer, J. Proton Transfer in Zeolites. In Hydrogen-Transfer Reactions; Hynes, J.T., Klinman, J.P., Limbach, H.-H., Schowen, R.L., Eds.; Wiley-VCH: Weinheim, Germany, 2006; pp. 685-707.

17. Chen, P.; Jabłońska, M.; Weide, P.; Caumanns, T.; Weirich, T.; Muhler, M.; Moos, R.; Palkovits, R.; Simon, U. Formation and Effect of $\mathrm{NH}_{4}{ }^{+}$Intermediates in $\mathrm{NH}_{3}-\mathrm{SCR}$ over Fe-ZSM-5 Zeolite Catalysts. ACS Catal. 2016, 6, 7696-7700. [CrossRef]

18. Sierka, M.; Sauer, J. Proton Mobility in Chabazite, Faujasite, and ZSM-5 Zeolite Catalysts, Comparison Based on Ab Initio Calculations. J. Phys. Chem. B 2001, 105, 1603-1613. [CrossRef]

19. Kanellopoulos, J.; Gottert, C.; Schneider, D.; Knorr, B.; Prager, D.; Ernst, H.; Freude, D. NMR Investigation of Proton Mobility in Zeolites. J. Catal. 2008, 255, 68-78. [CrossRef]

20. Liu, N.; Chen, B.; Li, Y.; Zhang, R.; Liang, X.; Li, Y.; Lei, Z. Charge Transfer Analysis on the Direct Decomposition of Nitrous Oxide over Fe-BEA Zeolite: An Experimental and Density Functional Study. J. Phys. Chem. C 2011, 115, 12883-12890. [CrossRef]

21. Huo, H.; Peng, L.; Grey, C.P. Low Temperature ${ }^{1}$ H MAS NMR Spectroscopy Studies of Proton Motion in Zeolite HZSM-5. J. Phys. Chem. C 2009, 113, 8211-8219. [CrossRef]

22. Derouane, E.G.; Védrine, J.C.; Pinto, R.R.; Borges, P.M.; Costa, L.; Lemos, M.; Lemos, F.; Ribeiro, F.R. The Acidity of Zeolites: Concepts, Measurements and Relation to Catalysis: A Review on Experimental and Theoretical Methods for the Study of Zeolite Acidity. Catal. Rev. 2013, 55, 454-515. [CrossRef]

23. Brüggemann, T.C.; Keil, F.J. Theoretical Investigation of the Mechanism of the Oxidation of Nitrogen Oxide on Iron-Form Zeolites in the Presence of Water. J. Phys. Chem. C 2011, 115, 2114-2133. [CrossRef]

24. Sajith, P.K.; Shiota, Y.; Yoshizawa, K. Role of Acidic Proton in the Decomposition of NO over Dimeric Cu(I) Active Sites in Cu-ZSM-5 Catalyst: A QM/MM Study. ACS Catal. 2014, 4, 2075-2085. [CrossRef]

25. Chen, P.; Schönebaum, S.; Simons, T.; Rauch, D.; Moos, R.; Simon, U. In Situ Monitoring of DeNO $\mathrm{DCR}^{-\mathrm{SCR}}$ Zeolite Catalysts by Means of Simultaneous Impedance and DRIFT Spectroscopy. Procedia Eng. 2015, 120, 257-260. [CrossRef]

26. Chen, P.; Schönebaum, S.; Simons, T.; Rauch, D.; Dietrich, M.; Moos, R.; Simon, U. Correlating the Integral Sensing Properties of Zeolites with Molecular Processes by Combining Broadband Impedance and DRIFT Spectroscopy-A New Approach for Bridging the Scales. Sensors 2015, 15, 28915-28941. [CrossRef] [PubMed]

27. Chen, P.; Simböck, J.; Schönebaum, S.; Rauch, D.; Simons, T.; Palkovits, R.; Moos, R.; Simon, U. Monitoring $\mathrm{NH}_{3}$ Storage and Conversion in Cu-ZSM-5 and Cu-SAPO-34 Catalysts for $\mathrm{NH}_{3}$-SCR by Simultaneous Impedance and DRIFT Spectroscopy. Sens. Actuators B 2016, 236, 1075-1082. [CrossRef] 
28. Simons, T.; Chen, P.; Rauch, D.; Moos, R.; Simon, U. Sensing Catalytic Conversion: Simultaneous DRIFT and Impedance Spectroscopy for in Situ Monitoring of $\mathrm{NH}_{3}-\mathrm{SCR}$ on Zeolites. Sens. Actuators B 2016, 224, 492-499. [CrossRef]

29. Chen, P.; Rauch, D.; Weide, P.; Schönebaum, S.; Simons, T.; Muhler, M.; Moos, R.; Simon, U. The Effect of Cu and Fe Cations on $\mathrm{NH}_{3}$-supported Proton Transport in $\mathrm{DeNO}_{x}$-SCR Zeolite Catalysts. Catal. Sci. Technol. 2016, 6, 3362-3366. [CrossRef]

30. Simons, T.; Simon, U. Zeolites as Nanoporous, Gas-sensitive Materials for in Situ Monitoring of DeNO $\mathrm{N}_{\mathrm{x}}-\mathrm{SCR}$. Beilstein J. Nanotechnol. 2012, 3, 667-673. [CrossRef] [PubMed]

31. Chen, P.; Moos, R.; Simon, U. Metal Loading Affects the Proton Transport Properties and the Reaction Monitoring Performance of Fe-ZSM-5 and Cu-ZSM-5 in NH 3 -SCR. J. Phys. Chem. C 2016, 120, 25361-25370. [CrossRef]

32. Franke, M.E.; Simon, U.; Moos, R.; Knezevic, A.; Muller, R.; Plog, C. Development and Working Principle of an Ammonia Gas Sensor Based on a Refined Model for Solvate Supported Proton Transport in Zeolites. Phys. Chem. Chem. Phys. 2003, 5, 5195-5198. [CrossRef]

33. Franke, M.E.; Simon, U. Solvate-supported Proton Transport in Zeolites. ChemPhysChem 2004, 5, 465-472. [CrossRef] [PubMed]

34. Rodriguez-Gonzalez, L.; Rodriguez-Castellon, E.; Jimenez-Lopez, A.; Simon, U. Correlation of TPD and Impedance Measurements on the Desorption of $\mathrm{NH}_{3}$ from Zeolite H-ZSM-5. Solid State Ion. 2008, 179, 1968-1973. [CrossRef]

35. Rauch, D.; Dietrich, M.; Simons, T.; Simon, U.; Porch, A.; Moos, R. Microwave Cavity Perturbation Studies on H-form and $\mathrm{Cu}$ Ion-Exchanged SCR Catalyst Materials: Correlation of Ammonia Storage and Dielectric Properties. Top. Catal. 2016. [CrossRef]

36. Rauch, D.; Kubinski, D.; Simon, U.; Moos, R. Detection of the Ammonia Loading of a Cu Chabazite SCR Catalyst by a Radio Frequency-based Method. Sens. Actuators B 2014, 205, 88-93. [CrossRef]

37. Barsoukov, E.; Macdonald, J.R. Impedance Spectroscopy: Theory, Experiment, and Applications, 2nd ed.; John Wiley \& Sons, Inc.: Hoboken, NJ, USA, 2005.

38. Simon, U.; Franke, M.E. Electrical Properties of Nanoscaled Host-guest Compounds. Microporous Mesoporous Mater. 2000, 41, 1-36. [CrossRef]

39. Simon, U.; Flesch, U. Cation-cation Interaction in Dehydrated Zeolites X and Y Monitored by Modulus Spectroscopy. J. Porous Mater. 1999, 6, 33-40. [CrossRef]

40. Dragomirova, R.; Wohlrab, S. Zeolite Membranes in Catalysis-From Separate Units to Particle Coatings. Catalysts 2015, 5, 2161-2222. [CrossRef]

41. Tolle, P.; Kohler, C.; Marschall, R.; Sharifi, M.; Wark, M.; Frauenheim, T. Proton Transport in Functionalised Additives for PEM Fuel Cells: Contributions from Atomistic Simulations. Chem. Soc. Rev. 2012, 41, 5143-5159. [CrossRef] [PubMed]

42. Zheng, Y.; Li, X.; Dutta, P.K. Exploitation of Unique Properties of Zeolites in the Development of Gas Sensors. Sensors 2012, 12, 5170-5194. [CrossRef] [PubMed]

43. Rodríguez-González, L.; Simon, U. $\mathrm{NH}_{3}$-TPD Measurements Using a Zeolite-based Sensor. Meas. Sci. Technol. 2010, 21, 027003. [CrossRef]

44. Paolucci, C.; Verma, A.A.; Bates, S.A.; Kispersky, V.F.; Miller, J.T.; Gounder, R.; Delgass, W.N.; Ribeiro, F.H.; Schneider, W.F. Isolation of the Copper Redox Steps in the Standard Selective Catalytic Reduction on Cu-SSZ-13. Angew. Chem. Int. Ed. 2014, 53, 11828-11833. [CrossRef] [PubMed]

45. Janssens, T.V.W.; Falsig, H.; Lundegaard, L.F.; Vennestrøm, P.N.R.; Rasmussen, S.B.; Moses, P.G.; Giordanino, F.; Borfecchia, E.; Lomachenko, K.A.; Lamberti, C.; et al. A Consistent Reaction Scheme for the Selective Catalytic Reduction of Nitrogen Oxides with Ammonia. ACS Catal. 2015, 5, 2832-2845. [CrossRef]

46. Gao, F.; Zheng, Y.; Kukkadapu, R.K.; Wang, Y.; Walter, E.D.; Schwenzer, B.; Szanyi, J.; Peden, C.H.F. Iron Loading Effects in Fe/SSZ-13 $\mathrm{NH}_{3}$-SCR Catalysts: Nature of the Fe Ions and Structure-Function Relationships. ACS Catal. 2016, 6, 2939-2954. [CrossRef]

47. Andonova, S.; Tamm, S.; Montreuil, C.; Lambert, C.; Olsson, L. The Effect of Iron Loading and Hydrothermal Aging on One-pot Synthesized Fe/SAPO-34 for Ammonia SCR. Appl. Catal. B 2016, 180, 775-787. [CrossRef]

48. Brandenberger, S.; Kröcher, O.; Tissler, A.; Althoff, R. The Determination of the Activities of Different Iron

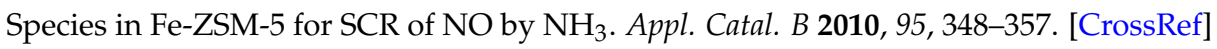


49. Gao, F.; Walter, E.D.; Karp, E.M.; Luo, J.; Tonkyn, R.G.; Kwak, J.H.; Szanyi, J.; Peden, C.H.F. Structure-Activity Relationships in $\mathrm{NH}_{3}$-SCR over Cu-SSZ-13 as Probed by Reaction Kinetics and EPR Studies. J. Catal. 2013, 300, 20-29. [CrossRef]

50. Gao, F.; Washton, N.M.; Wang, Y.; Kollár, M.; Szanyi, J.; Peden, C.H.F. Effects of Si/Al Ratio on Cu/SSZ-13 $\mathrm{NH}_{3}$-SCR Catalysts: Implications for the Active Cu Species and the Roles of Brønsted Acidity. J. Catal. 2015, 331, 25-38. [CrossRef]

51. Kwak, J.H.; Lee, J.H.; Burton, S.D.; Lipton, A.S.; Peden, C.H.; Szanyi, J. A Common Intermediate for $\mathrm{N}_{2}$ Formation in Enzymes and Zeolites: Side-on Cu-nitrosyl Complexes. Angew. Chem. Int. Ed. 2013, 52, 9985-9989. [CrossRef] [PubMed]

52. Ruggeri, M.P.; Selleri, T.; Colombo, M.; Nova, I.; Tronconi, E. Identification of Nitrites/HONO as Primary Products of NO Oxidation over Fe-ZSM-5 and Their Role in the Standard SCR Mechanism: A Chemical Trapping Study. J. Catal. 2014, 311, 266-270. [CrossRef]

53. Gao, F.; Wang, Y.; Kollár, M.; Washton, N.M.; Szanyi, J.; Peden, C.H.F. A Comparative Kinetics Study between $\mathrm{Cu} /$ SSZ-13 and Fe/SSZ-13 SCR Catalysts. Catal. Today 2015, 258, 347-358. [CrossRef]

54. Gunter, T.; Carvalho, H.W.; Doronkin, D.E.; Sheppard, T.; Glatzel, P.; Atkins, A.J.; Rudolph, J.; Jacob, C.R.; Casapu, M.; Grunwaldt, J.D. Structural Snapshots of the SCR Reaction mechanism on Cu-SSZ-13. Chem. Commun. 2015, 51, 9227-9230. [CrossRef] [PubMed]

55. Moos, R.; Müller, R.; Plog, C.; Knezevic, A.; Leye, H.; Irion, E.; Braun, T.; Marquardt, K.-J.; Binder, K. Selective Ammonia Exhaust Gas Sensor for Automotive Applications. Sens. Actuators B 2002, 83, 181-189. [CrossRef]

56. Takata, T.; Tsunoji, N.; Takamitsu, Y.; Sadakane, M.; Sano, T. Nanosized CHA Zeolites with High Thermal and Hydrothermal Stability Derived from the Hydrothermal Conversion of FAU Zeolite. Microporous Mesoporous Mater. 2016, 225, 524-533. [CrossRef]

57. Hu, X.; Yang, M.; Fan, D.; Qi, G.; Wang, J.; Wang, J.; Yu, T.; Li, W.; Shen, M. The Role of Pore Diffusion in Determining $\mathrm{NH}_{3} \mathrm{SCR}$ Active Sites over Cu/SAPO-34 Catalysts. J. Catal. 2016, 341, 55-66. [CrossRef]

58. Feng, B.; Wang, Z.; Sun, Y.; Zhang, C.; Tang, S.; Li, X.; Huang, X. Size Controlled ZSM-5 on the Structure and Performance of Fe Catalyst in the Selective Catalytic Reduction of $\mathrm{NO}_{x}$ with $\mathrm{NH}_{3}$. Catal. Commun. 2016, 80, 20-23. [CrossRef]

59. Severance, M.; Zheng, Y.; Heck, E.; Dutta, P.K. Influence of Crystallite Size on Cation Conductivity in Faujasitic Zeolites. J. Phys. Chem. A 2013, 117, 13704-13711. [CrossRef] [PubMed]

60. Mintova, S.; Jaber, M.; Valtchev, V. Nanosized Microporous Crystals: Emerging Applications. Chem. Soc. Rev. 2015, 44, 7207-7233. [CrossRef] [PubMed]

61. Dapsens, P.Y.; Mondelli, C.; Perez-Ramirez, J. Design of Lewis-acid Centres in Zeolitic Matrices for the Conversion of Renewables. Chem. Soc. Rev. 2015, 44, 7025-7043. [CrossRef] [PubMed]

62. Buurmans, I.L.; Weckhuysen, B.M. Heterogeneities of Individual Catalyst Particles in Space and Time as Monitored by Spectroscopy. Nat. Chem. 2012, 4, 873-886. [CrossRef] [PubMed]

63. Saltzmann, T.; Bornhofft, M.; Mayer, J.; Simon, U. Shape without Structure: An Intriguing Formation Mechanism in the Solvothermal Synthesis of the Phase-Change Material $\mathrm{Sb}_{2} \mathrm{Te}_{3}$. Angew. Chem. Int. Ed. 2015, 54, 6632-6636. [CrossRef] [PubMed]

(C) 2016 by the authors; licensee MDPI, Basel, Switzerland. This article is an open access article distributed under the terms and conditions of the Creative Commons Attribution (CC-BY) license (http://creativecommons.org/licenses/by/4.0/). 